\title{
Social Effects of Disasters as Actants: A Comparison of 1999 Marmara Earthquake, Turkey and 2004 Tsunami, Indonesia
}

\section{Aktant Olarak Afetlerin Sosyal Etkileri: 1999 Marmara Depremi ile 2004 Endonezya Tsunami Karşılaştırması}

\author{
Zuhal Yonca ODABAŞ, Günnur ERTONG \\ Ankara Üniversitesi Dil ve Tarih-Coğrafya Fakültesi Sosyoloji Bölümü, Ankara
}

\begin{abstract}
Although disasters such as earthquake and tsunami are widely accepted as natural phenomena, with regard to their effects to the societies in terms of social, economical, political, and cultural spheres, in this paper it is assumed that these disasters are social facts. By using basic concepts of Actor Network Theory, social effects of 1999 Marmara Earthquake, Turkey and 2004 Tsunami, Indonesia are compared. Although methodological limitations of this theory in using quantitative techniques, the results of surveys conducted one year after both Marmara Earthquake and 2004 Tsunami are also used to increase the propositions of Actor Network Theory. The study revealed that disasters as actant lead several changes in many relations at economic, political, and cultural spheres of society such as solidarity, education, family relations in both countries.
\end{abstract}

Keywords: Disaster, Actor Network Theory, Actant/Actor, Earthquake, Tsunami.

\begin{abstract}
Özet: Doğal afetler olarak kabul edilen deprem ya da tsumami gibi olaylar, sosyal ekonomik, politik ve kültürel alanlaradki etkileri nedeni ile bu çalışma kapsamında sosyal olgular olarak değerlendirilmektedir. Aktör İlişkilerağı Kuramı'nın temel kavramları kullanılarak 1999 Marmara Depremi ile 2004 yılında Endonezya'da meydana gelen tsunaminin sosyal etkileri karşılaştırılmaktadır. Her ne kadar, teori nicel bilgi toplama tekniklerine karşı sinırlı olsa da, her iki afetten bir yıl sonra gerçekleştirilen alan araştırmasının sonuçları, teorinin önermelerini destekler niteliktedir. Araștırma sonucunda, her iki afetin de ekonomik, politik ve kültürel alanlarda (dayanışma, aile ilişkileri, gibi) önemli değişikliklere neden olduğu ortaya çımaktadır.

Anahtar kelimeler: Afet, Aktör İlişkileră̆ı Kuramı, Actant/Aktör, Deprem, Tsunami.
\end{abstract}

\section{Introduction}

The concept of disaster consists of latent meaning of human associations. For a destructive event to qualify as a disaster, it must occur in social unity and disrupt social order for a while (Fritz, 1961; Ploughman, 1997). Despite the clear distinction between natural and human made disasters (Giddens, 1998), there have been debates on this classification for decades (Kumar, 2000). According to the critics of this classification, these two facts are not independent from each other and the concept of "hybrid" plays an important role in these discussions. They further argue that despite the fact that a disaster is recognized at the first sight only as natural or human made, if it is examined more deeply, it can be seen that it carries the characteristics of both types.

Latour (2004) and his colleagues developed a new theory which is against all kinds dichotomies (as nature-culture, structure-agent, subject-object and so on) that exist in modern social science. They claim that these dichotomies are not able to explain or understand the social reality with all aspects of it, and because of this there is a need to establish a link between them (the dichotomies). This theory, which is called Actor Network Theory (ANT), pays more attention to the term of associations rather than the concept of social._According to it, both human and non-human beings have equal importance. In other words, in relations neither human (actor) nor non-human (actant) has a great role. In the modern world, everything works within a network (Latour, 1998), and to understand action, relations in these networks must be studied. The theory itself has a descriptive character in examining how and 


\section{Z.Y.Odabaş and G.Ertong}

why heterogenic associations come together or dissolve. Among concepts of this theory 'translation' and 'black box' are used in this paper. Actually, translation is a process in which the macro actor/actant imposes his/her/its reality. At the end of it, if other actors/actants in the network accept the truth of the macro one, there exists a black box in which the legality of main actor/actants is accepted; otherwise, this black box will be destructed. In other words, the basic requirement for the emergence of a network is consensus on an idea, and this consensus can be treated as trust. If this consensus is questioned, then the black box is opened. In that case, the network could weaken or completely disappear. This may result in the emergence of new networks or transformations of the existing ones.

The Actor Network Theory provides the appropriate analytical tools for analyzing the multiple dimensions in natural hazards and environmental problems such as earthquakes, tsunamis or floods, (Burges et al. 2000). The emphasis on rejecting dualities and paying more attention to relations overlaps the fact that those natural events as disasters have hybrid characters (Murphy, 2004).

\section{Disaster as an Actant}

According to Latour (1998), the concept of an actant corresponds to non-human beings and is similar to human beings in the sense that it has its own rationality in which it can act. Because of this, it carries as much importance as human beings in actions. In this paper, due to its social, cultural, economic, physical, and psychological effects on the society in which it occurs, a disaster is accepted as an actant. Based on this assumption, this study examines the way networks were constructed after the Marmara earthquake in Turkey in 1999 and the Banda Aceh tsunami in Indonesia in 2004.

Despite the geographical differences, Turkey and Indonesia have cultural similarities due to having Islam as the predominant religion. In addition, there are historical similarities between Turkey and the province of Banda Aceh. Both countries experienced in the recent past two destructive natural events: 1999 Marmara Earthquake in Turkey and 2004 Tsunami in Indonesia. In the earthquake in the Marmara region of Turkey in 1999, five large cities were affected. According to official statistics 18,000 people died, 50,000 people were injured, 5,000 houses were destructed, and more than 340,000 houses were damaged. In addition to this, 14,513 work places were closed, 150,000 people became unemployed and 129,338 people started to live in temporary houses (Kasapoğlu and Ecevit, 2004).

The effects of the tsunami in Aceh were enormous. The disaster had a devastating impact on both the social and economic structure of the city. Because of the tsunami on December 26, 2005, 306,544 people lost their life. Most of these people lived in the coastal areas of Southeast and South Asia, and the majority of them (168,095 and 55\%) were from the Nanggroe Aceh Darussalam province. (Pribadi, 2005).

A primary characteristic of a disaster is its ability to destroy the status-quo of a society. According to the Actor Network Theory this status-quo can be treated as a network. In this network there are many actors/actants who/which already accept the legality of the main actor/actant. However, after a disaster and after the collapse or destruction of the status quo, members of the society start to question the main actors/actants and the black box is opened. These main actors/actants can be political, economic or cultural leaders, rules, applications, values and beliefs which are already accepted and trusted as normal in a given society before a disaster occurs. As a result of this, new processes could start and members of the society might develop different political, economic and socio-cultural beliefs, attitudes and behaviors which could result in the emergence of new and/or transformed networks. In other words, there is a strong possibility for the process of transformation to start. Within this process, people could start to distrust the leaders of given areas (problematization), question the relationships between close environments such as family, friends etc. (interessement), develop new ways of coping with these problems (enrollment), or enter other networks with the new identity (mobilization of alliances). The main research problem of this study is the collapse of statusquo both in Turkey and Indonesia after the destructive disasters. In this paper, with the assumption that there can be different relations in variant networks, the experiences of disasters in Turkey and 
Indonesia are compared. Although there are methodological limitations in the Actor Network Theory regarding the application of quantitative techniques, in order to strengthen the propositions of the theory, the results of surveys conducted in Turkey and Indonesia are also presented.

This paper specifically aims to seek answers to the following questions regarding the people who experienced an earthquake or a tsunami:

1. What differences and changes have occurred in the lives of people in Turkey and Indonesia after an earthquake or a tsunami?

2. To what extent, are there differences or similarities in these changes between the two countries?

\section{Method}

The data for the 1999 Marmara Earthquake in Turkey were gathered a year after the earthquake from the five cities affected by the disaster.. Each province was included in the sample according to its population density. The household was the sample unit and 250 households were selected according to a stratified random-sampling technique. In particular, proportional stratified sampling was used and two people from each household were included (one man one women). A total of 500 people were interviewed. The data for the 2004 Tsunami in Indonesia were collected a year after the disaster in the province of Banda Aceh. In the tsunami survey, the sample unit was also a household. Unlike the other survey, only one person from each family was interviewed (144 people in total).

Since the same interview schedule was used in both surveys, it can be asserted that this paper is partially a cross-cultural study. In the interview form, there were demographic questions such as gender, age, education level, marital status, income, employment status and so on. Also there were Likert-type questions about the relations among family members, friends, relatives as well as about trust to the state and government.

One part of the interview schedule, "Verbal Commitment"(Hines et all., 1986/87) was used as an independent psychological variable. This was measured with the following question: "Would you participate to any campaign in order to help the victims of any disaster that can occur in Turkey/Indonesia?". The "yes" answers were scored with one point and "no" answers with zero.

In order to measure the status of modernity, participants were asked question such as "What is the most important thing for you?". Among the options in the answers, "having a job" was accepted as a criterion of modernity and coded as one point. The other option "having a house" was treated as a feature of traditionalism and coded as zero.

As a final independent variable in this paper, some Likert-type of questions were asked to the survivors about their worries (Kamano, 1999) on various problems such as unemployment, the occurrence of another earthquake, environmental problems, establishment of nuclear plants, the possibility of a war breaking out, illness, and traffic accidents.

Paired sample T-tests, regression analysis and zero order correlation analysis were applied in order to attain the research objectives.

\section{Findings and Discussion}

The research findings are assumed to be more informative when certain basic demographic data about the sample are provided: In the Turkish sample, the sex distribution is quite similar to the actual distribution in the society: $48.6 \%$ of the respondents are female and $51.4 \%$ male. The average age is 42.6 with a 11.0 standard deviation. The education level in the sample has the following distribution: $7,6 \%$ are illiterate; $4,0 \%$ are literate without a diploma; $49,8 \%$ are primary school graduates; $9,4 \%$ secondary school graduates, $16,9 \%$ high school graduates and $12,2 \%$ have university degrees. For the 


\section{Z.Y.Odabaş and G.Ertong}

sample of Indonesia, the sex distribution is as follows: $50.3 \%$ of the respondents are female and $49.7 \%$ are male. The average age in the sample is 33.2 with a standard deviation of 11.6. The distribution of education level in the sample is as follows: $2,8 \%$ illiterate; $2,1 \%$ literate without a diploma; $12,6 \%$ primary school graduate; $22,4 \%$ secondary school graduate; $60,1 \%$ with higher education.

\section{Translation of Networks}

Disaster as an actant affects the social life of communities. As discussed in the introduction section, there were changes after both the earthquake in Turkey and the tsunami in Indonesia. According to Table 1, disasters positively and negatively affected certain social relations, attitudes, behaviors, and conditions of survivors. While the solidarity among relatives, close friends, neighbors, and fellow citizens decreased after the disasters in both countries, the solidarity among family members in Indonesia increased after the tsunami. After these disasters there was also a worsening in the educational status of children, in economic conditions, and in trust towards the state in both countries. In addition to these changes, there was an increase in the knowledge on disasters as well as on religious beliefs and practices. In accordance with the Actor Network Theory, in these changes it is possible to see the process of translation of networks of solidarity, marriage, economic status, education, trust to state, belief in religion, knowledge of disasters.

Table1. Comparisons of several futures /conditions before and after the disaster between Turkey and Indonesia (N for Turkey $=500 ; \mathrm{N}$ for Indonesia $=144$ ).

\begin{tabular}{|c|c|c|c|c|c|}
\hline Futures/conditions & Country & $\begin{array}{l}\text { Means } \\
\text { Before }\end{array}$ & $\begin{array}{c}\text { Means } \\
\text { After }\end{array}$ & $\begin{array}{c}\text { Paired } \\
\text { difference }\end{array}$ & $\begin{array}{l}\text { T values and } \\
\text { significance }\end{array}$ \\
\hline $\begin{array}{lll}\begin{array}{l}\text { Solidarity } \\
\text { members }\end{array} & \text { among } & \text { family } \\
\end{array}$ & $\begin{array}{l}\text { Turkey } \\
\text { Indonesia }\end{array}$ & $\begin{array}{l}3,69 \\
3,71\end{array}$ & $\begin{array}{l}3,59 \\
3,72\end{array}$ & $\begin{array}{l}-, 10 \\
, 01\end{array}$ & $\begin{array}{l}3,283 * * * \\
-, 111\end{array}$ \\
\hline Solidarity among relatives & $\begin{array}{l}\text { Turkey } \\
\text { Indonesia }\end{array}$ & $\begin{array}{l}3,32 \\
3,61\end{array}$ & $\begin{array}{l}3,19 \\
3,59\end{array}$ & $\begin{array}{l}-, 13 \\
-, 02\end{array}$ & $\begin{array}{l}3,685^{* * *} \\
, 396\end{array}$ \\
\hline Solidarity among close friends & $\begin{array}{l}\text { Turkey } \\
\text { Indonesia }\end{array}$ & $\begin{array}{l}3,50 \\
3,59\end{array}$ & $\begin{array}{l}3,42 \\
3,47\end{array}$ & $\begin{array}{l}-, 08 \\
-, 12\end{array}$ & $\begin{array}{l}2,455^{* *} \\
2,346^{*}\end{array}$ \\
\hline Solidarity among neighbors & $\begin{array}{l}\text { Turkey } \\
\text { Indonesia }\end{array}$ & $\begin{array}{l}3,49 \\
3,55\end{array}$ & $\begin{array}{l}3,44 \\
3,50\end{array}$ & $\begin{array}{l}-, 05 \\
-, 05\end{array}$ & $\begin{array}{l}1,708 \\
1,152\end{array}$ \\
\hline Solidarity among fellow citizens & $\begin{array}{l}\text { Turkey } \\
\text { Indonesia }\end{array}$ & $\begin{array}{l}3,24 \\
2,69\end{array}$ & $\begin{array}{l}3,17 \\
2,65\end{array}$ & $\begin{array}{l}-, 07 \\
-, 04\end{array}$ & $\begin{array}{l}2,469 * * \\
, 758\end{array}$ \\
\hline $\begin{array}{l}\begin{array}{l}\text { Trust for the state and } \\
\text { government }\end{array} \\
\end{array}$ & $\begin{array}{l}\text { Turkey } \\
\text { Indonesia }\end{array}$ & $\begin{array}{l}2,15 \\
3,06\end{array}$ & $\begin{array}{l}2.01 \\
3,00\end{array}$ & $\begin{array}{l}-, 14 \\
-, 06\end{array}$ & $\begin{array}{l}3,770 * * * \\
1,578\end{array}$ \\
\hline Knowledge about disasters & $\begin{array}{l}\text { Turkey } \\
\text { Indonesia }\end{array}$ & $\begin{array}{l}1,77 \\
1,67 \\
\end{array}$ & $\begin{array}{l}3,06 \\
2,28 \\
\end{array}$ & $\begin{array}{l}1,29 \\
, 61\end{array}$ & $\begin{array}{l}-24,709 * * * \\
-7,777 * * * \\
\end{array}$ \\
\hline Religious beliefs and practices & $\begin{array}{l}\text { Turkey } \\
\text { Indonesia }\end{array}$ & $\begin{array}{l}3,14 \\
3,70\end{array}$ & $\begin{array}{l}3,16 \\
3,79\end{array}$ & $\begin{array}{l}02 \\
, 09\end{array}$ & $\begin{array}{l}-577 \\
-1,824\end{array}$ \\
\hline Education of children & $\begin{array}{l}\text { Turkey } \\
\text { Indonesia }\end{array}$ & $\begin{array}{l}3,18 \\
3,32\end{array}$ & $\begin{array}{l}2,71 \\
3,20\end{array}$ & $\begin{array}{l}-, 53 \\
-, 12\end{array}$ & $\begin{array}{l}11,522 * * * \\
1,700\end{array}$ \\
\hline Desire for Migration & $\begin{array}{l}\text { Turkey } \\
\text { Indonesia }\end{array}$ & $\begin{array}{l}1,46 \\
1,45\end{array}$ & $\begin{array}{l}1,69 \\
1,60\end{array}$ & $\begin{array}{l}, 23 \\
, 15\end{array}$ & $\begin{array}{l}-5,001 * * * \\
-2,404 *\end{array}$ \\
\hline Economic conditions & $\begin{array}{l}\text { Turkey } \\
\text { Indonesia }\end{array}$ & $\begin{array}{l}2,93 \\
2,65 \\
\end{array}$ & $\begin{array}{l}2,39 \\
2,49 \\
\end{array}$ & $\begin{array}{l}-, 54 \\
-, 16 \\
\end{array}$ & $\begin{array}{l}12,960 * * * \\
4,172 * * *\end{array}$ \\
\hline Desire for divorce & $\begin{array}{l}\text { Turkey } \\
\text { Indonesia }\end{array}$ & $\begin{array}{l}1,27 \\
1,07\end{array}$ & $\begin{array}{l}1,31 \\
1,34\end{array}$ & $\begin{array}{l}, 04 \\
, 27\end{array}$ & $\begin{array}{l}-1,754 \\
-1,664\end{array}$ \\
\hline
\end{tabular}

$* \mathrm{p}<.05 ; * * \mathrm{p}<.01 ; * \mathrm{p}<.000$

Drabek et al. (1975) assert that it is common to see an increase in solidarity among relatives right after a disaster; however, in the long term, a decrease in this kind of behavior is very likely. The surveys used in this paper were conducted a year after the disasters, and it is possible to say that the findings of this paper are in accordance with Drabek et al.'s claims. Also in accordance with Drabek et al.'s claim, Palamut (2007) showed a fall among relative networks seven years after the 1999 Marmara Earthquake in Kocaeli. Clark( 2005 ) asserts that the time just after a disaster is the time of generosity. 
In other words, it is common to see high density of donations from organizations, governments and citizens just after a disaster. However, in the long term these donations decline. This situation negatively affects the survivors who are not yet able to maintain their lives without outside help and who do not trust others, particularly the state and government. (Kasapoglu and Ecevit, 2004). In the cases of both Turkey and Indonesia, survivors experienced these kinds of feelings. Another effect that lead to a decline in the trust to the state and government in both cases was the late interventions after the disasters struck. .The victims in Turkey blamed the state for not responding immediately and at present they do not expect much from the government (Jalali, 2002 ; Kasapoğlu et al. 2004). In Indonesia, it is asserted that (Hamid and Jeliteng, 2005) the coordination provided by the government was inadequate and the prevailing bureaucratic culture was just too slow to deal with such an emergency.

Experiencing a devastating disaster is one of the main ways to get information about it (Shaw and Goda, 2004). According to the results of paired differences, survivors of both disasters already developed consciousness about what a disaster is.

Rippote et al. (1987) state that fatalism and religiosity are the often seen reactions among the survivors of a devastating event. As indicated before, a disaster leads to the collapse of existing networks in a society. As a result, victims look for new or strong support. In this case religion is one of the strongest (Sattler, et al,2000).

Because of their destructive power, disasters damage both physical and social environments of any given society. The institution of education is one of them. Losses of teachers, students and other stuff as well as the destruction of schools lead to an interruption of education. For instance, in Indonesia after the tsunami, over 2,000 schools were destroyed or damaged, and some 45,000 students and 1,870 teachers were killed. Most of these losses were in the public sector, and the local and provincial infrastructure that supports school services were severely damaged (Inderfurth et al. 2005). Similarly, in Turkey after the Marmara Earthquake, education in the disaster areas was disrupted and it was resumed in tents with the help of volunteers. These educational activities involved particularly psychological support given by experts (Karanci et al.1999)

According to Table 1, the survivors of the two disasters desire to migrate to safe places more than before. As Boon and Tra (2007) assert, human beings always move from one place to another in order to acquire new and better settlements and living conditions than before. Most of the time, the main underlying reasons to this fact are wars, social conflicts and environmental disasters. This claim is confirmed once again in the cases of Turkey and Indonesia.

Another sector that was affected negatively from both the Marmara earthquake and the Aceh tsunami was the economy. The tsunami devastated coastal communities in the affected areas. Fishing, small-scale agriculture, and tourism were particularly hard hit. Infrastructure and private assets were lost or damaged along the coasts. Some studies have shown that the overall economic impact on more developed countries could be smaller than that in poor countries (Inderfurth et al., 2005). The region affected by the Marmara earthquake in Turkey is the industrial heartland of economy (Bibbee et al, 2000). Because of the extensiveness of the affected area, the economic cost was very high. The damage in energy, transport and communication sectors was particularly heavy. In addition to this, many people lost their jobs.

The final social result of any disaster examined in this paper is the breakdown in family ties (Ehrenreich, 2001; Kumar-Range, 2001). After disasters family dynamics might be altered. Disasters might cause divorce and family separations. Individual problems that occur after disasters lead to conflicts in family relations. In the wake of a disaster, marital conflict and distress rise. Moreover, increases in the divorce rate in the months following disasters may occur. The result of Table 1 shows these kinds of facts that emerged after the earthquake in Turkey and the tsunami in Indonesia.

In Table 2 and Table 3, the results of zero order correlations between some demographic variables and certain measures for both countries are presented. For the victims of 1999 Marmara 


\section{Z.Y.Odabaş and G.Ertong}

Earthquake (Table 2), the highest positive correlations are that between the worries about some problems and gender (.098) and that between verbal commitment and measure of modernity (.090). According to the correlation test results, negative relationships between variables are more significant than the positive ones. Education and gender (-.170), education and age (-.161), modernity measure and education (-.155) and finally worry and education level (-.158) are more significant relations than others.

Table 2. Zero order correlation for Turkey

\begin{tabular}{|c|c|c|c|c|c|}
\hline Variables & 1 & 2 & 3 & 4 & 5 \\
\hline $\begin{array}{l}\text { 1. Gender } \\
\text { Women }=1\end{array}$ & - & & & & \\
\hline 2. Age &,$- 142 * *$ & - & & & \\
\hline 3. Education &,$- 170 * * *$ &,$- 161 * * *$ & - & & \\
\hline 4.Modernity & ,046 & ,023 &,$- 155 * * *$ & - & \\
\hline $\begin{array}{l}\text { 5.Verbal } \\
\text { commitment }\end{array}$ & ,004 &,- 065 &, 030 & ,090* & \\
\hline $\begin{array}{l}\text { 6. Worry. } \\
\text { (Mean=20,19 } \\
\text { St. } D=4,09 \text { Alpha=,72) }\end{array}$ & ,098* &,$- 103^{*}$ &,$- 158 * * *$ & ,007 & ,006 \\
\hline
\end{tabular}

In the case of survivors of the 2004 tsunami in Indonesia, the only positive correlation is between verbal commitment and age (.188). Similar to the results of Turkish sample, negative correlations are more significant than the positive and it is between education and age (-.370).

Table 3: Zero order correlation for Indonesia

\begin{tabular}{|l|l|l|l|l|l|}
\hline Variables & 1 & 2 & 3 & 4 & 5 \\
\hline $\begin{array}{l}\text { 1. Gender } \\
\text { Women=1 }\end{array}$ & - & & & & \\
\hline 2. Age &,- 119 & - & & & \\
\hline 3. Education &, 041 &,$- 370^{* * *}$ & - & & \\
\hline Modernity &, 055 &, 035 &, 031 & - & \\
\hline $\begin{array}{l}\text { Verbal } \\
\text { Commitment }\end{array}$ &,- 035 &, $188^{*}$ &,- 145 &,- 010 & \\
\hline $\begin{array}{l}\text { 6. Worry. } \\
\left(\begin{array}{l}\text { Mean }=15,93 \\
\text { St.D }=2,99 \text { Alpha }=, 75)\end{array}\right.\end{array}$ &, 083 &,- 012 &, 137 &, 029 &, 166 \\
$* \mathrm{p}<.05 ; * * \mathrm{p}<.01 ; * \mathrm{p}<.000$ & & & & & \\
\hline
\end{tabular}

Kasapoğlu and Ecevit (2001) claim that there is a positive relationship between education and a lower level of alienation and worry among survivors of the Marmara earthquake. Although there is no significant relationship between gender and worry about some problems in the case of Indonesia, women are the most affected population from the tsunami. In Indonesia more women than men died and those who survived had greater responsibility in caring for family members than before with limited resources. Similar to Indonesia, also in Turkey, women were affected more by the disaster and felt themselves under depression more than men (Karanc1 et al., 1999). Sattler et al(2000) state that loss of resources is one of main factors that increase psychological stress. They also note that this stress and worry can be decreased when social support is provided.

Although there is no significant relationship in the sample of Indonesia, Wickrama and Kapsar (2007) assert that because of prolonged displacement or loss of physical environment, social loss (loss 


\section{Social Effects of Disasters as Actants: A Comparison of 1999 Marmara Earthquake, Turkey and 2004 Tsunami, Indonesia}

of school and friends) and family loss (increased family conflicts) after the tsunami, mental health of victims were negatively affected. They started to feel disappearing of their future and became more vulnerable than ever before.

\section{Conclusion}

The Actor Network Theory puts emphasis on hybrid entities and their process of building networks. Because of this feature, this theory provides useful analytical tools for examining environmental problems. In this paper, by using this perspective, the impacts of 1999 Marmara earthquake in Turkey and 2004 tsunami in Banda Aceh in Indonesia are compared.

The results of comparisons between Turkey and Indonesia of several features/conditions before and after the disaster revealed that in both countries solidarity among relatives increased and solidarity among close friends and neighbors decreased because relatives from other cities were the first who came to help while neighbors and friends were the victims of the same disaster who were not able to help each other. After these disasters, there was deterioration in the educational status of children, in economic conditions, and in trust towards the state in both countries. In addition to these changes, there was also an increase in both knowledge about disasters and religious beliefs and practices. After these destructive events, the survivors of both countries' disasters wanted to divorce and migrate to other places more than before. According to the results of regression analysis for the victims of the 1999 Marmara earthquake, there are positive correlations between worry about some problems and gender and between verbal commitment and measure of modernity. In the case of survivors of 2004 tsunami in Indonesia, the only positive correlation is between verbal commitment and age.

Indonesia and Turkey are two countries that experienced devastating disasters in the recent past. This is not the only similarity between two countries. The main common point is Islam, and religion has a strong influence on people's way of understanding and interpretation of the world. Therefore, it could be claimed that similar responses might be derived from cultural factors. However, it should also be noticed that there exist similarities between the responses in these Islamic societies and in Western societies. This contradicts the view that the responses of survivors in Islamic societies to disasters might be different from others - especially Western societies -, and the main reason to this difference might be religion. However, our results reveal that most features of the responses of survivors in these two societies to disasters were similar to those in Western societies. The decline in solidarity (except between relatives) and trust, the increase in the desire to migrate and divorce, educational and economical problems are some of the areas that exhibit similarities between Western and non-Western societies.

The main underlying reason for declining solidarity in various parts of traditional societies might be globalization through the media. Due to the important role they play during and after disasters, information technologies diminish differences by making them more uniform. However, this fact can still account for only part of the change. It seems that economic factors play an important role by applying an influential power to change the prevailing values of a given society, even in more traditional and conservative countries like Turkey and Indonesia. Based on this pioneering and limited survey results, detailed qualitative studies should be carried out in order to reduce the material and life losses by preparing them for future disasters.

\section{References}

Boon, K., Tra, T. L. 2007 ‘Are Environmental Refugees Refused?', Std. Tribes Tribals, 5(2): 85-95.

Burges, J., Clark, J., Harrison, M.C.2000 'Knowledges in Action: An Actor Network Analysis of a Wetland AgriEnvironment Scheme', Ecological Economics 35 (2000): 119-132

Clark, N.2005 'Disaster and Generosity', Geographical Journal,171(4):384 - 386 


\section{Z.Y.Odabaş and G.Ertong}

Drabek, T.E., Key, W.H., Erickson, P., Crowe, J.L. 1975 ‘The Impact of Disaster on Kinship Relations', Journal of Marriage and Family, 37(3):481-494.

Ehrenreich, J.H. 2001 Coping with Disasters: a Guidebook to Psychological Intervention, http://www.mhwwb.org/CopingWithDisaster.pdf

Fritz, C.1961. 'Disasters' in. R. Merton \& R. Nisbet (ed.), Contemporary Social Problems, Sage

Giddens, A. 1998 'Risk Society: The Context of British Policies', in j. Franklin (ed) The Politics of risk Society, Polity Press

Hamid, H., Jeliteng 2001 Bila Warga Menilai: Satu Tahun Rekonstruksi Aceh (If Citizens Evaluate, Reconstruction in Aceh after One After Tsunami),

http://www.acehrecoveryforum.org/id/index.php?action=Artikel\&no=4\&q=ONE\%20YEAR\%20OF\%20POSTTSUNAMI\%20WORK

Hines, J.M.,Hungerford, H.R.,Tomera, A.N.1986/1987 'Analysis and Synthesis of Research on Responsible Environmental Behavior: A Meta Analysis, Journal of Environmental Education, 18(2):1-8.

Inderfurth, .K.F., Fabrycky, D., Cohen, S. 2005 The 2004 Indian Ocean Tsunamı: S1x Month Report June 2005, http://www.chaitanyaconsult.in/chaitanya/guide/scapfinal.pdf

Jalali, R. 2002 'Civil Society and the State: Turkey After the State’, Disasters, 26(2):120-139

Kamano, S. 1999 'Comparing Individual Attitudes in Seven Countries’, Social Science Research, 28(1):1-35.

Karanc1, N. A., Alkan, N., Akşit, B., Sucuoğlu, H., Balta, E. 1999 'Gender Differences in Psychological Distress, Coping, Social Support, and Related Variables Following the 1995 Dinar, Turkey Earthquake', North American Journal of Psychology, 1(2): 189-204.

Kasapoğlu, A. ve Ecevit M. 2001 Depremin Sosyolojik Araştırması, Ankara: Ümit.

Kasapoğlu, A., Ecevit, M. 2004 'Impact of several Worry Factors on Responsible Behavior: The Case of 1999 Earthquake in Turkey' . International Journal of Mental Health, 33:13-30.

Kasapoğlu, A., Ecevit, Y., Ecevit, M. 2004 'Support Needs of Survivors of The August 17,1999 Earthquake in Turkey', Social Indicators Research ,66:229-248.

Kumar, G. S. J. 2000 'Disaster Management and Social Development', International Journal of Sociology and Social Policy, 20(7):66-81.

Kumar-Range, S. 2001 Environmental Management and Disaster Risk Reduction:

A Gender Perspective, http://www.un.org/womenwatch/daw/csw/env_manage/documents/BP1-2001Nov04.pdf

Latour, B. 1998 Keynote Speech: On Recalling ANT, http://comp.lancs.ac.uk/sociology/stslatour1.html

Latour, B. 2004 'The Social as Association', in N. Gane (ed) The Future of Social Theory, Continuum.

Murphy, R. 2004 'Disaster or Sustainability: The Dance of Human Agents with Nature's Actants,' The Canadian Reuiew of Sociology and Anthropology 41(3):249-266

Palamut,H.2007 'Depremin Yarattığı Travmanın Kişilerin Hayatlarına Etkileri: Gölcük Örneği (Earthquake Related Trauma and its effects on Victims in Gölcük/Turkey)' in A. Kasapoğlu(ed), Yeni Toplumsal Travmalar (New Societal Traumas), Ankara

Ploughman, P.1997 'Disasters, the Media and Social Structures: A Typology of Credibility Hierarchy Persistence Based on Newspaper Coverage of the Love Canal and Six Other Disasters', Disasters, 21(2):118-137.

Pribadi, J. 2005Country studies on how the catastrophe and subsequent: a case of Aceh, Aceh Recovery Form, $\mathrm{http} / /$ www.acehrecoveryforum.org/id/index.php?action=Artikel\&no=3\&q=Country\%20studies\%20on $\% 20$ how $\% 20 \mathrm{t}$ he $\% 20$ catastrophe $\% 20$ and $\% 20$ subsequent: $\% 20 \mathrm{a} \% 20$ case $\% 20$ of $\% 20$ Aceh

Rippote, P.A. and Rogers, R.W. 1987 'Effects of Protection-Motivation Theory on Adaptive and Maladaptive Coping with a health threat', Journal of Personality and Social Psychology, 52(3): 596-604.

Shaw, R., Katsuihciro, G. 2004 'From Disaster to Sustainable Civil Society: The Kobe Experience', Disasters, 2004, 28(1): $16-40$

Sattler, D. N., Kaiser, C.F.,Hittner, J.B. 2000 'Disaster preparedness: relations Among Prior Experience, Personal characteristics, and Distress', Journal of Applied Social Psychology,30(7):1396-1420

Wickrama, K.A.S., Kapsar, V. 2007 'Family context of mental health risk in Tsunami-exposed Adolescents: Findings from a Pilot Study in Sri Lanka', Social Science \& Medicine,64: 713-723 